\title{
Seroprevalence and associated risk factors of ovine neosporosis worldwide: a systematic review and meta- analysis
}

\section{Soroprevalência e fatores de risco associados à neosporose ovina no mundo: uma revisão sistemática e metanálise}

Paulo Roberto Romanelli1; Eloiza Teles Caldart ${ }^{1 *}$; Felippe Danyel Cardoso Martins ${ }^{2}$; Camila Marinelli Martins ${ }^{3}$; Andressa Maria Rorato Nascimento de Matos ${ }^{4}$; Fernanda Pinto-Ferreira ${ }^{1}$; Marcelle Mareze ${ }^{2}$; Regina Mitsuka-Breganó1; Roberta Lemos Freire ${ }^{1}$; Italmar Teodorico Navarro ${ }^{1}$

\section{Highlights}

The pooled estimated seroprevalence of ovine neosporosis worldwide is $12 \%$.

The use of IFAT or ELISA in the diagnosis is not a source of data heterogeneity. Dogs on the farms was not confirmed by meta-analysis as the main risk factor.

\begin{abstract}
Neosporosis, caused by the protozoan Neospora caninum, has been widely reported and discussed as a major disease associated with reproductive problems in herds of various animal species. This study aimed to perform a systematic review and meta-analysis on the prevalence and risk factors associated with ovine neosporosis worldwide. This is the first systematic review, which was performed according to the established preferred reporting items in systematic reviews and meta-analyses (PRISMA) guidelines to address ovine neosporosis. Four databases were used in this study: PubMed, SciELO, Web of Science, and Scopus. The selected keywords were "neospora AND sheep," "neosporosis AND sheep," "neospora AND lamb," "neosporosis AND lamb," "neospora AND ewe," and "neosporosis AND ewe." The meta-analysis calculations were performed with random-effects models for proportions, and heterogeneity was tested using the $\mathrm{I}^{2}$ test. This study identified 24 studies on ovine neosporosis, nine of which evaluated the factors

1 Profs. Drs., Department of Preventive Veterinary Medicine, State University of Londrina, UEL, Londrina, PR, Brazil. E-mail: pauloromanell@yahoo.com.br; eloizacaldart@uel.br;, fernandaferreira@uel.br; rbregano@uel.br; rlfreire@uel. br; italmar@uel.br

2 Students of the Postgraduate Program in Animal Science, UEL, Londrina, PR, Brazil. E-mail: felippemartins@hotmail. com; marcelle_mareze@hotmail.com

${ }^{3}$ Profa Dra, Department of Medicine, State University of Ponta Grossa, UEPG, Ponta Grossa, PR, Brazil. E-mail: camilamarinelli@gmail.com

${ }^{4}$ Master Profa, Department of Preventive Veterinary Medicine, UEL, Londrina, PR, Brazil. E-mail: andressa.rorato@uel.br

* Author for correspondence
\end{abstract}

Received: Aug. 05, 2020 - Approved: Nov. 30, 2020 
associated with the risk of seropositivity. After meta-analysis, the pooled estimated prevalence was $12 \%$ (95\% Cl, 8-16\%; $I^{2} p$-value < 0.01). The evaluation of the included studies allowed the identification of ovine neosporosis distribution in continents according to demonstrated prevalence rates. We confirmed via metaanalysis that the use of indirect immunofluorescence assay (IFAT) or enzyme-linked immunosorbent assay (ELISA) in the diagnosis of ovine neosporosis was not a source of data heterogeneity. The presence of dogs on the properties was reported as the main risk factor associated with the occurrence of ovine neosporosis; however, this was not confirmed by the meta-analysis.

Key words: Neosporosis. Sheep. Heterogeneity. Diagnosis method.

\section{Resumo}

A neosporose, causada pelo protozoário Neospora caninum, tem sido amplamente relatada e discutida como uma das principais doenças associadas a problemas reprodutivos em rebanhos de várias espécies animais. Este estudo teve como objetivo realizar uma revisão sistemática e meta-análise sobre a prevalência e os fatores de risco associados à neosporose ovina em todo o mundo. Esta é a primeira revisão sistemática, que foi realizada de acordo com os itens de relatório preferidos estabelecidos em revisões sistemáticas e diretrizes de meta-análises (PRISMA) para tratar da neosporose ovina. Quatro bases de dados foram utilizadas neste estudo: PubMed, SciELO, Web of Science e Scopus. As palavras-chave selecionadas foram "neospora AND sheep", "neosporose AND sheep", "neospora AND lamb", "neosporose AND lamb", "neospora AND ewe" e "neosporose AND ewe". Os cálculos da meta-análise foram realizados com modelos de efeitos aleatórios para proporções, e a heterogeneidade foi testada usando o teste $\mathrm{I}^{2}$. Este estudo identificou 24 estudos sobre neosporose ovina, nove dos quais avaliaram os fatores associados ao risco de soropositividade. Após a meta-análise, a prevalência estimada combinada foi de 12\% (IC 95\%, 8-16\%; I2 valor de $\mathrm{p}<0,01)$. A avaliação dos estudos incluídos permitiu identificar a distribuição da neosporose ovina nos continentes de acordo com as prevalências demonstradas. Confirmamos por meio de meta-análise que o uso de ensaio de imunofluorescência indireta (IFI) ou ensaio de imunoabsorção enzimática (ELISA) no diagnóstico de neosporose ovina não foi uma fonte de heterogeneidade de dados. A presença de cães nas propriedades foi relatada como o principal fator de risco associado à ocorrência de neosporose ovina; no entanto, isso não foi confirmado pela meta-análise..

Palavras-chave: Neosporose. Ovino. Heterogeneidade. Método diagnóstico.

\section{Introduction}

The first case of Neospora caninum infection in sheep was described by Dubey, Hartley, Lindsay and Topper (1990), in a newborn lamb that showed neurological signs and death within one week of life, the authors used an immunohistochemical technique and ultrastructural analysis on brain tissue to the diagnosis.
Experiments have been conducted on parasite behavior in this host. McAllister et al. (1996) demonstrated that experimental infection at the beginning of gestation $(65$ days) with $1.7 \times 10^{5}$ or $1.7 \times 10^{6}$ tachyzoites resulted in abortion in all animals; however, experimental infection in the final phase of gestation (120 days) resulted in clinically healthy animals. Therefore, abortion outcome is related to the gestational period where the 
$N$. caninum infection occurs, and it has been described that ewe infection during the initial gestation results in uncontrolled parasite proliferation. In the middle of gestation, some important placental lesions leads to abortion; infection at the end of gestation could not lead to abortion mainly because of the short period between infection and birth, and is also possibly due to a more mature fetal immune response (Arranz-Solís et al., 2016).

Since abortion represents an important economic loss in ovine flocks, $N$. caninum prevalence determination based on serologic tests has been extensively performed in different settings throughout the world. The first estimated prevalence of neosporosis in sheep was $9.5 \%$ in general ovine population and $4.24 \%$ in ewes with reproductive dysfunction (Helmick, Otter, Mcgarry, \& Buxton, 2002; Romanelli, 2002). Nevertheless, most prevalence studies do use this approach in infectious disease epidemiology.

Regarding the epidemiology in ovine populations, some studies have demonstrated variables related to dogs as associated factors; other studies describe specific factors, such as management specificities (Abo-Shehada \& Abu-Halaweh, 2010; Al-Majali, Jawasreh, Talafha, \& Talafha, 2008; Arraes-Santos et al., 2016; Rocha et al., 2014). Even though some similar factors were found in different studies and locations, a systematic review coupled with meta-analysis, aiming to estimate the pooled prevalence and combined associated factors, will help to advance our knowledge regarding this infection.

This study aimed to perform a systematic review and meta-analysis of the prevalence and risk factors associated with ovine neosporosis worldwide.

\section{Methodology}

This systematic review was performed according to the Preferred Reporting of Items in Systematic Reviews and MetaAnalyses guidelines (Moher et al., 2009). Five investigators $(1,2,3,4$, and 5$)$ searched four science publication databases: PubMed, SciELO, Web of Science, and Scopus. The search parameters were distributed to the researchers, who employed the boolean operator "AND"; the keywords were as follows: "neospora AND sheep" and "neosporosis AND sheep" (researchers 1 and 2), "neospora AND lamb" and "neosporosis AND lamb" (researchers 3 and 4), and "neospora AND ewe" and "neosporosis AND ewe" (researcher 5).

The criterion for article inclusion was articles in English or Portuguese that investigated the prevalence and/or outbreak and risk factors for the occurrence of the disease. The exclusion criterion was articles evaluating the diagnostic methods in live animals. Based on the database queries, each researcher used the Mendeley ${ }^{\circledR}$ program (Elsevier, Amsterdam) to analyze the file libraries generated by each database, excluding duplicates, empty files, and nonrelevant titles and abstracts. After the article selection, the files were converted into a BibTex format (.bib), grouped into a single folder in the Mendeley ${ }^{\circledR}$ program, and analyzed according to the criteria mentioned above.

Meta-analysis calculations were performed with random-effects models for proportions, and heterogeneity was tested with the $\mathrm{I}^{2}$ test with the "metaprop" function of the "meta" package (Schwarzer, 2007) in the R environment (R Core Team [R], 2017). Forest plots were generated for the descriptive analysis of the results, and funnel 
plots were generated to verify the occurrence of publication bias. A general model was constructed for all studies identified in the systematic review involving IFAT, ELISA, and Brazil and its different regions. The level of significance considered in this study was $95 \%$.

The identified risk factors analyzed in the meta-analysis were abortion occurrence on the property, presence of dogs, presence of wild animals, and contact between goats and sheep. In these models, pooled odds ratios (ORs) were calculated with the "scalar" and "rma" functions of the "metafor" package (Viechtbauer, 2010) in the R environment.

\section{Results and Discussion}

We identified 2,968 articles from the database. All steps of the screening were evaluated in the Mendeley ${ }^{\circledR}$ program (Figure 1), and 24 articles remained. By reading the full texts, we verified that 15 articles presented data on only the prevalence of neosporosis in sheep (Figure 2), and nine articles presented the prevalence and risk factors for the disease (Table 1). Fifteen studies were conducted in Brazil, and the rest were conducted in North America (1), South America (1), Europe (2), the Middle East (3), Africa (1), and Asia (1). All included publications were conducted between 2004 and 2016 (Figure 3).

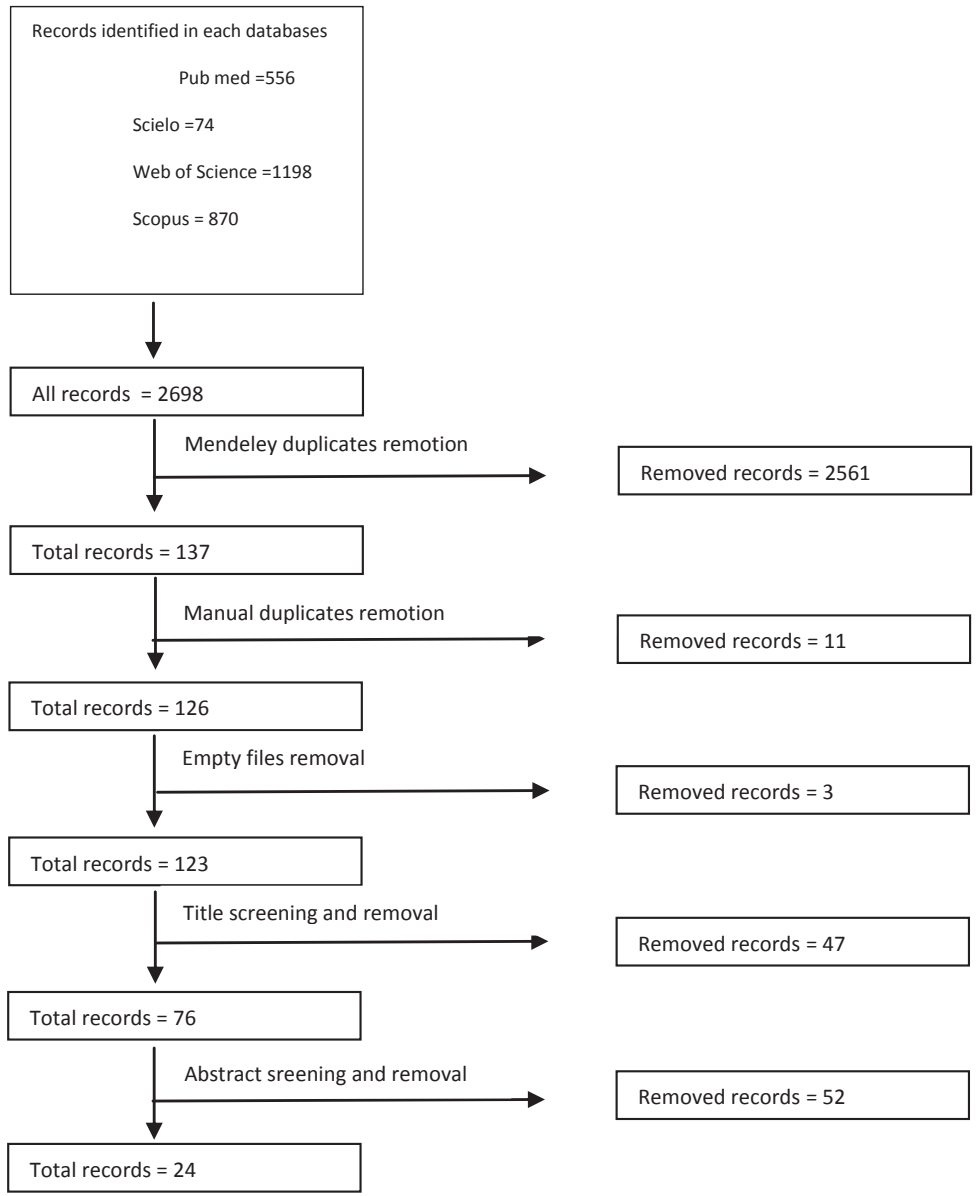

Figure 1. Flow diagram with total records and selection process performed at each stage of the worldwide systematic review on ovine neosporosis and associated factors. 


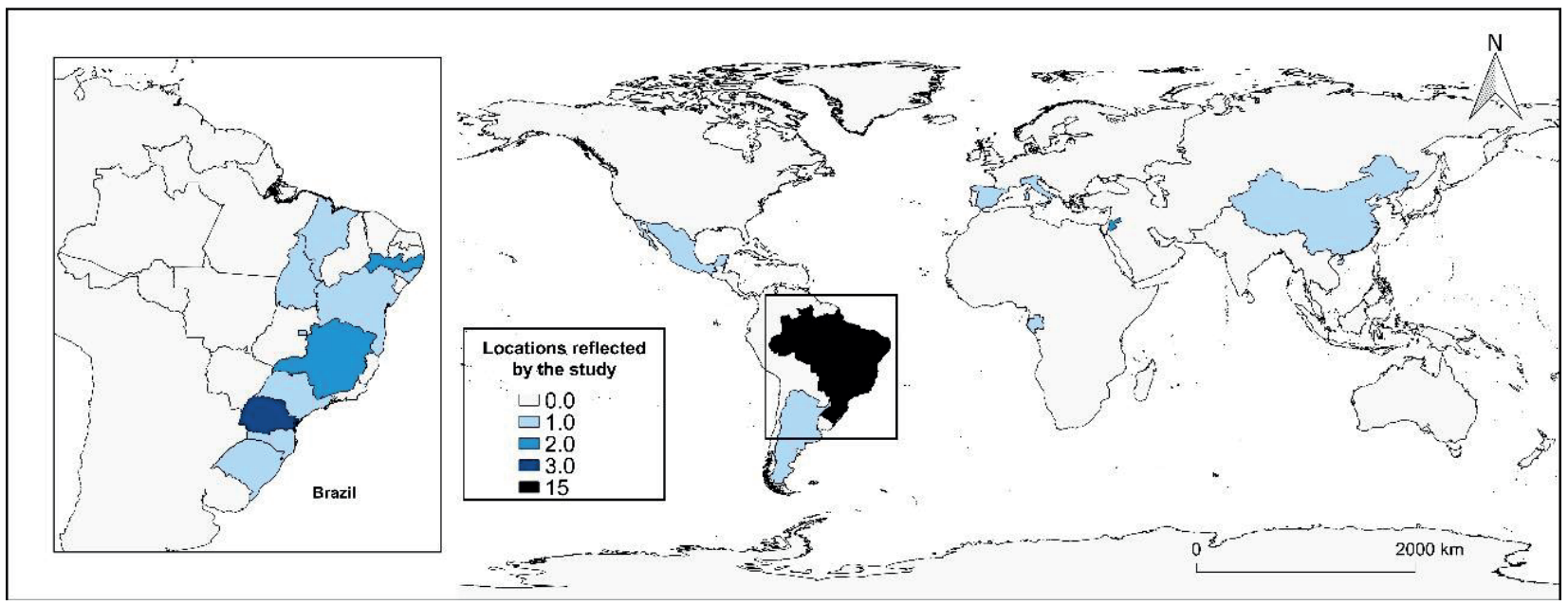

Figure 2. Thematic map with the number of articles from each country and Brazilian states included in the worldwide systematic review on ovine neosporosis and associated factors.

\begin{tabular}{|c|c|c|c|c|}
\hline Author & State & Positives/Total & Prevalence (\%) & Method \\
\hline Figliuolo et al., 2004 & São Paulo & $55 / 597$ & $9.2 \%$ & IFAT \\
\hline Romanelli et al., 2007 & Paraná & $29 / 305$ & $9.5 \%$ & IFAT \\
\hline Ueno et al., 2009 & Distrito Federal & $90 / 1028$ & $8.7 \%$ & IFAT \\
\hline Munhóz et al., 2010 & Paraná & $53 / 381$ & $13.9 \%$ & IFAT \\
\hline $\begin{array}{c}\text { Salaberry, S. R. S., Okuda, L. H., } \\
\text { Nassar, A. F. C., Castro, J. R., } \\
\text { Lima-Ribeiro, A. M. C., 2010 }\end{array}$ & Minas Gerais & $27 / 334$ & $8.1 \%$ & IFAT \\
\hline Moraes et al., 2011 & Maranhão & $3 / 64$ & $4.7 \%$ & IFAT \\
\hline Tembue et al., 2011 & Pernambuco & $52 / 81$ & 64.2 & IFAT \\
\hline Andrade et al., 2012 & Minas Gerais & $64 / 488$ & $13.1 \%$ & IFAT \\
\hline Hecker et al., 2013 & Argentina & $21 / 704$ & $3.0 \%$ & IFAT \\
\hline Gharekhani et al., 2013 & Iran & $8 / 358$ & $2.2 \%$ & ELISA \\
\hline $\begin{array}{c}\text { Castañeda-Hernández, Cruz- } \\
\text { Vázquez, \& Medina-Esparza., } \\
\text { 2014 }\end{array}$ & México & $18 / 324$ & $5.5 \%$ & ELISA \\
\hline Moura et al., 2014 & Santa Catarina & $92 / 1308$ & $7.0 \%$ & IFAT \\
\hline Guimarães et al., 2015 & Tocantins & $25 / 182$ & $13.7 \%$ & IFAT \\
\hline $\begin{array}{c}\text { Gheller, Carniel, Carrasco, \& } \\
\text { Seki, 2016 }\end{array}$ & Paraná & $3 / 81$ & $3.7 \%$ & IFAT \\
\hline $\begin{array}{c}\text { Ferreira, Vogel, Sangioni, Cezar, } \\
\& \text { Menezes, 2016 }\end{array}$ & Rio Grande do Sul & $49 / 300$ & $16.3 \%$ & IFAT \\
\hline
\end{tabular}

Figure 3. Studies on ovine neosporosis seroprevalence without risk factor analysis included in the worldwide systematic review on ovine neosporosis and associated factors. 


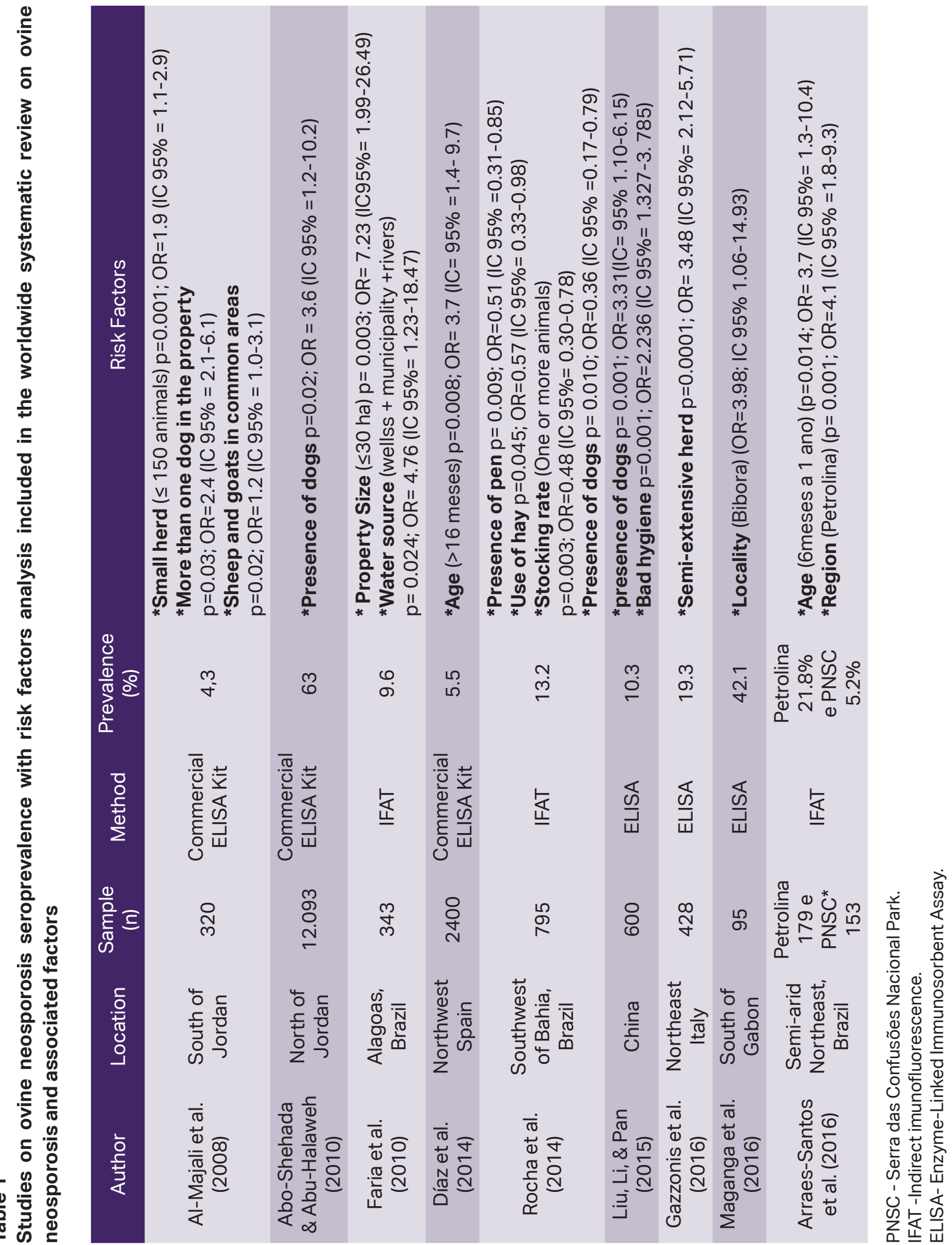


No publication bias was observed in the funnel plot. According to the meta-analysis, the prevalence was $12 \%(95 \% \mathrm{Cl}, 8-16 \%$; Figure 4), and there was no difference between the studies using IFAT and ELISA (Table 2). The meta-analysis prevalence results according to geographic area are presented in Table 3.
The models of neosporosis risk-associated factors revealed non-significant pooled ORs for all the variables analyzed: presence of dogs, abortion occurrence, contact between sheep and goats, and presence of wild animals (Table 4).

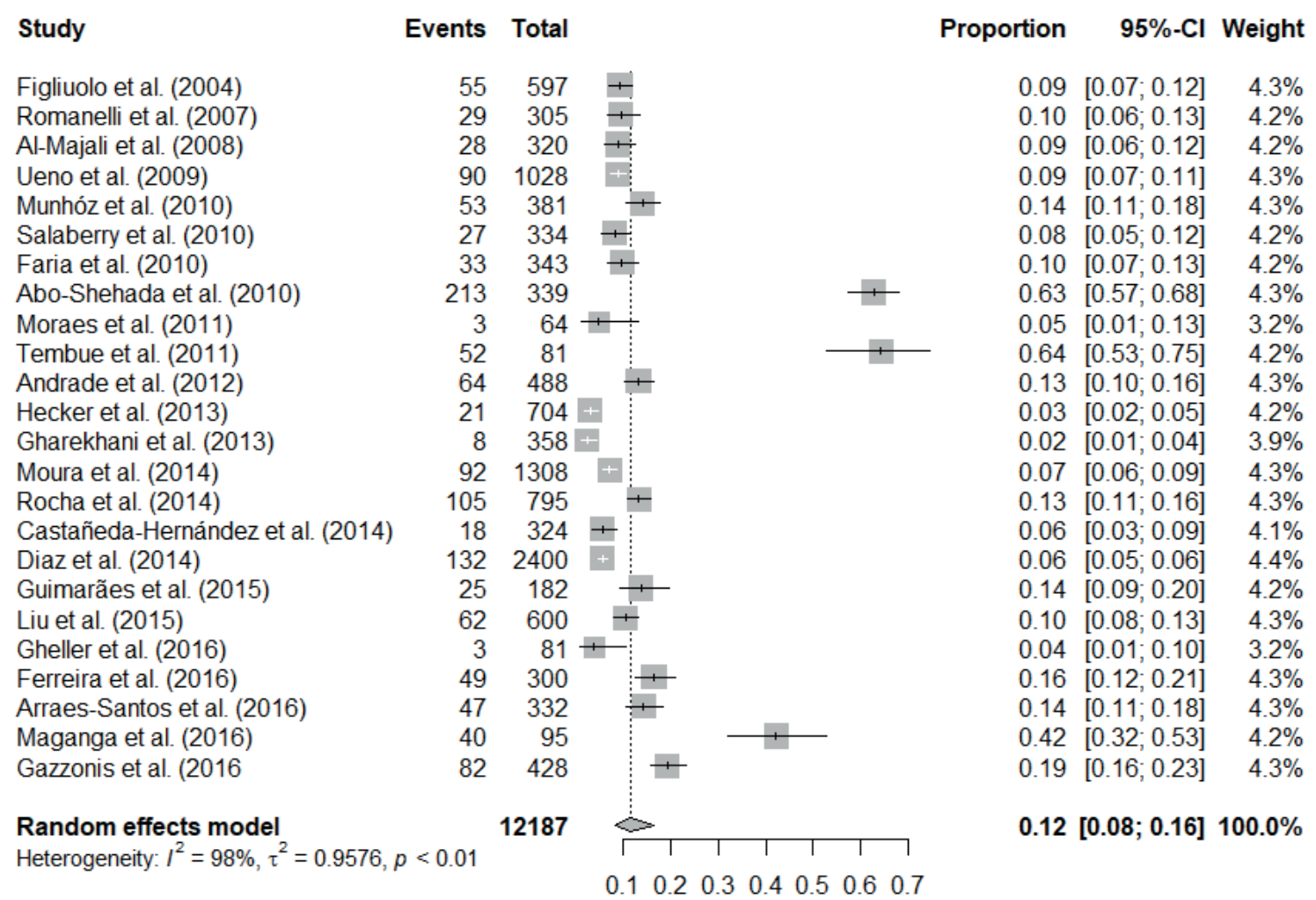

Figure 4. Forest plot with the pooled seroprevalence and individual seroprevalences from studies included in the worldwide systematic review on ovine neosporosis and associated factors.

\section{Table 2}

Prevalence meta-analysis models and heterogeneity test $p$-value from studies included in the worldwide systematic review on ovine neosporosis and associated factors

\begin{tabular}{cccc|} 
& Combined Effect & $95 \%$ IC & $I^{2} p$-value \\
\hline General & $12 \%$ & $8-16 \%$ & $<0.01$ \\
IFAT & $11 \%$ & $8-15 \%$ & $<0.01$ \\
ELISA & $13 \%$ & $3-39 \%$ & $<0.01$
\end{tabular}


Table 3

Prevalence meta-analysis models stratified by different geographic areas calculated from the studies included in the worldwide systematic review on ovine neosporosis and associated factors

\begin{tabular}{|c|c|c|c|}
\hline Geographic Area & Combined Effect & $95 \% \mathrm{Cl}$ & $l^{2} p$-value \\
\hline World & $12 \%$ & $8-16 \%$ & $<0.01$ \\
\hline South America & $10 \%$ & $7-13 \%$ & $<0.01$ \\
\hline Brazil & $12 \%$ & $9-16 \%$ & $<0.01$ \\
\hline North & $14 \%$ & $9-20 \%$ & NT \\
\hline Northeast & $17 \%$ & $8-21 \%$ & $<0.01$ \\
\hline Midwest & $9 \%$ & $7-11 \%$ & NT \\
\hline Southeast & $10 \%$ & $8-13 \%$ & $=0.04$ \\
\hline South & $10 \%$ & $7-15 \%$ & $<0.01$ \\
\hline
\end{tabular}

NT - no heterogeneity test was performed, since only one study was selected for the said region.

Table 4

Risk factors meta-analysis models and heterogeneity test $p$-value calculated from studies included in the worldwide systematic review on ovine neosporosis and associated factors

\begin{tabular}{|cccc|}
\hline & OR & $95 \%$ IC & $I^{2}$ p-value \\
\hline Occurrence of abortion & 2.70 & $0.86-8.46$ & 0.039 \\
\hline Presence of dogs & 1.22 & $0.58-2.59$ & 0.004 \\
\hline Ovine and caprine sharing the same area & 0.75 & $0.33-1.69$ & 0.170 \\
\hline Presence of wild animals & 1.27 & $0.40-3.97$ & 0.112 \\
\hline
\end{tabular}

This study presents a systematic review and meta-analysis on the seroprevalence of $N$. caninum and the risk factors associated with seropositivity in sheep worldwide. Selected studies presented seroprevalence rates ranging from $2 \%$ in Iran to $64 \%$ in Brazil (Gharekhani, Tavoosidana, \& Zandieh, 2013; Tembue et al., 2011). A combined rate of $12 \%$ was observed in the meta-analysis when the 24 studies were included in the analysis. This reflected the rates in most studies, although there were some exceptions, such as the study by Abo-Sehada and Abu-Halaweh (2010) in Jordan, Tembue et al. (2011) in Brazil, and Maganga et al. (2016) in Gabon, with 63\%,
$64 \%$, and $42 \%$ seroprevalence, respectively. Maganga et al. (2016) reported that $62 \%$ of sheep presented reproductive problems, such as abortions and/or stillbirths, demonstrating the possibility of an outbreak of reproductive disease caused by $N$. caninum, justifying the high positivity.

Regarding the methodology used for serodiagnosis (ELISA or IFAT), a small but nonsignificant difference between the combined effects was observed, indicating that the choice of the technique was not a factor that contributed to the heterogeneity in the results; therefore, future studies can be performed 
with either method without compromising the reliability of the results.

The most significant differences were in three Brazilian regions: North (14\%), Northeast (17\%), and Central-West (9\%). The North and Midwest Regions were represented by only one study, which was not enough to represent the entire region and was probably responsible for this difference. However, the Northeast Region had a high seroprevalence, as reported by Tembue et al. (2011) and discussed above.

The meta-analysis on factors associated with neosporosis risk in sheep showed that none of the analyzed variables was statistically significant in the combined analysis, which may be explained by the heterogeneity among the studies.

In the northwest region of Spain, Díaz et al. (2014) evaluated 2,400 animals and found a prevalence of $5.5 \%$, and in multivariate analysis, the variable "age (> 16 months)" was associated with a 3.72 times greater chance of $N$. caninum infection in the studied herds. With the advancement of age, females enter the reproductive life stage, contributing to the vertical transmission of the disease; the animals also increase the likelihood of contact with various agent transmission routes, resulting in horizontal transmission. ArraesSantos et al. (2016) found a prevalence of 21.8\% (39/179) in Petrolina municipalities and $5.2 \%(8 / 153)$ in a National Park. Multivariate analysis revealed the variable "age $(6$ months to 1 year)" as a risk factor. The results indicated a $3.7 \%$ increase in the probability of infection in young animals in relation to adult. Regarding horizontal transmission, the period (age) of exposure to the sources of infection is very important. In vertical transmission, this factor is not as relevant; thus, an increased prevalence in young animals can be easily explained.

In the northeast region of Italy, Gazzonis et al. (2016) evaluated 428 animals and found a prevalence of $19.3 \%$. In multivariate analysis, the variable "semi-extensive herd" was associated with a 3.48-fold increase in odds for ovine neosporosis. According to Dubey and Schares (2011), in a semiextensive production system, the animals are supplemented with fodder and grains, which are stored in barns easily accessible to dogs; this practice poses a high risk of infection. The semi-extensive system results in a high animal agglomeration rate. Generally, the facilities are in the peri-domicile region where dogs are also present, increasing the chance of environmental contamination.

Faria et al. (2010) observed that small properties ( $\leq 30 \mathrm{ha}$ ) had 7.2-fold higher odds of neosporosis. Al-Majali et al. (2008) reported that a variable herd size (small $\leq 150$ animals) increased the odds of $N$. caninum infection by 1.9 -fold. Although neosporosis is not a highly infectious disease, the increased population density in sheep herds increases the possibility of animal contact with the source of infection and various transmission routes of $N$. caninum in the environment. Another consideration is the tendency for an agent to have a low prevalence due to good sanitary conditions and the adoption of good production practices in addition to low animal density, which is observed on large properties that generally have more technicians.

Faria et al. (2010) reported a 4.76fold increase in the risk of neosporosis when water came from mixed sources (wells + public supply + natural springs). The joint evaluation 
of different water sources did not allow the identification of the specific water source that was contaminated by oocysts, suggesting a bias. Since the authors did not find a positive association with water from wells alone in univariate analysis, it is possible to conclude that the water originating from natural springs was contaminated. Tzanidakis et al. (2012), who studied the risk factors associated with T. gondii in goats and sheep in Greece, stated that although the study revealed public water supply as a risk factor associated with the prevalence of the agent, it may be a confounding factor.

In Brazil, Arraes-Santos et al. (2016) found a positive association between the properties in the Petrolina region and the National Park (Parque Nacional Serra das Confusões) in terms of the seroprevalence of ovine neosporosis. There was a 4.1-fold risk of developing neosporosis, and the prevalence between the different regions or within the same region varied according to factors, such as temperature, humidity, and sanitary condition, as well as the characteristics of animal samples and definitive host presence (Ueno et al., 2009). It is possible that animals living in preserved areas, such as the National Park, where a small population of domestic dogs live, are less exposed to neosporosis than those in the Petrolina region. Nevertheless, even in preserved environments with less or absent domestic dogs, wild canids may maintain N. caninum in a sylvatic cycle (Almeida et al., 2019).

Barling et al. (2001) identified the use of hay as feed supplementation and the presence of a pen on the property as protective factors for the disease. Both variables decrease outdoor sheep grazing during the day in pastures that may be contaminated by oocysts; however, possible biases should be considered. This finding is controversial because it refutes the findings described by several authors concerning the presence of pens, which favor the agglomeration of sheep and when associated with the presence of dogs, increases the risk of infection.

Food supplementation has also been described as a risk factor for the disease since hay and feed are stored in barns where, on most properties, access by dogs is common; they spend time and defecate in the barns, contaminating the environment and food with $N$. caninum oocysts. Another variable, stocking rate (grazing stocking), may also be subject to bias since the authors reported a risk for the disease when there was less than one animal per hectare of pasture.

The presence of dogs on sheep farms has been described as one of the main and probably the most important variable associated with ovine neosporosis. Dubey and Schares (2011) reported the presence of dogs on farms as a major risk factor for $N$. caninum infection in cattle herds. They also mentioned that fodder and grains are stored in barns easily accessible to dogs.

According to Dijkstra, Barkena, Bjorkman and Wouda (2002), the maintenance of the agent biological cycle occurs through the elimination of oocysts in dog feces, which contaminate pastures, silage, or other sources of food. Al-Majali et al. (2008), who studied sheep herds in southern Jordan, reported that the presence of more than one dog on the property suggests horizontal transmission of the agent, increasing the risk of infection by 2.4-fold. Among herds in northern Jordan, AboShehada and Abu-Halaweh (2010) reported that the risk of neosporosis increased 3.6-fold. 
According to Abo-Sehada and AbuHalaweh (2010), the presence of dogs on the property was associated with the risk of neosporosis in sheep. In addition, the authors noted that dogs are integral members of small ruminant herds in the study region, with approximately $80 \%$ of the properties having two or more dogs. Additionally, the owners commonly fed the dogs with the viscera of dead animals. These local characteristics may explain the high seroprevalence. Tembue et al. (2011) did not evaluate the risk factors associated with seropositivity; however, they affirmed that $81.3 \%$ of the studied properties had dogs.

In China, Liu, Li and Pan (2015) reported that 3.3-fold increase in the risk of $N$. caninum infection was observed when dogs were present. Although these studies were carried out in different countries and periods, the strong association of the presence of dogs with ovine neosporosis may be because canids are definitive hosts of the agent. In this way, the risk can be avoided or reduced by restricting the access of dogs to production areas, as well as correct disposal of placental remains and viscera, preventing horizontal transmission, avoiding infection in dogs, and eliminating the oocysts in the environment (Silva et al., 2013).

Maganga et al. (2016) discovered that the sheep in Bibora, southern Gabon were approximately four times more likely to be infected with $N$. caninum than animals in other localities. This result can be explained by the high number of stray dogs in this locality, which is associated with poor waste management in rural communities, generating garbage dumps that serve as food sources for these dogs.
Poor sanitation in facilities with dogs is also a factor to be considered, especially those with feeders and drinking fountains that may be contaminated with the oocysts of the agent, as described by Cavalcante, Carneiro, Gouveia, Pinheiro and Vitor (2008), who investigated the risk factors of $T$. gondii infection in caprine herds in the state of Ceará. Liu et al. (2015) reported that the risk of neosporosis increased by 2.23 -fold when the properties have poor sanitation.

On the other hand, the presence of dogs was described as a protective factor from neosporosis in ovine herds by Rocha et al. (2014). In this scenario, Barling et al. (2001) stated that the presence of dogs on a property can inhibit the presence of stray dogs and wild canids, which could be responsible in transporting the pathogen between flocks.

\section{Conclusion}

The distribution of ovine neosporosis in continents has been demonstrated via prevalence data. The use of IFAT or ELISA in the diagnosis of ovine neosporosis was not a source of data heterogeneity. In the present study, the presence of dogs on the studied properties was the main risk factor associated with ovine neosporosis; however, this was not confirmed by the meta-analysis.

\section{References}

Abo-Shehada, M., \& Abu-Halaweh, M. (2010). Flock-level seroprevalence of, and risk factors for, Neospora caninum among sheep and goats in northern Jordan. Preventive Veterinary Medicine, 93(1), 2532. doi: 10.1016/j.prevetmed.2009.08.004 
Al-Majali, A. M., Jawasreh, K. I., Talafha, H. A., \& Talafha, A. Q. (2008). Neosporosis in sheep and different breeds of goats from southern jordan: prevalence and risk factors analysis. American Journal of Animal and Veterinary Sciences, 3(2), 4752.

Almeida, J. C. de, Kim, P. de C. P., Melo, R. P. B. de, Nogueira, J. F., Martins, F. D. C., Garcia, J. L.,... Mota, R. A. (2019). Neospora caninum DNAinfeces of crab-eating fox (Cerdocyon thous - Linnaeus, 1776) from northeastern Brazil. Acta Tropica, 197, 105068. doi: 10. 1016/j.actatropica.2019.105068

Andrade, G. S., Bruhna, F. R. P, Rocha, C. M. B. M., Guimarães, A. S., Gouveia, A. M. G., \& Guimarães, A. M. (2012). Seroprevalence and risk factors for Neospora caninum in sheep in the state Minas Gerais, southeastern Brazil. Veterinary Parasitology, 188(1-2), 168-171. doi: 10.10 16/j.vetpar.2012.03.006

Arraes-Santos, A. I., Araújo, A. C., Guimarães, M. F., Santos, J. R., Pena, H. F. J., Gennari, S. M.,... Horta, M. C. (2016). Seroprevalence of anti-Toxoplasma gondii and antiNeospora caninum antibodies in domestic mammals from two distinct regions in the semi-arid region of Northeastern Brazil. Veterinary Parasitology: Regional Studies and Reports, 5, 14-18. doi: 10.1016/j.vprsr. 2016.08.007

Arranz-Solís, D., Benavides, J., Regidor-Cerrillo, J., Horcajo, P., Castaño, P., Del CarmenFerreras, M.,... Ortega-Mora, L. M. (2016). Systemic and local immune responses in sheep after Neospora caninum experimental infection at early, mid and late gestation. Veterinary Research, 47(1), 1-13. doi: 10.1186s13567-015-0290-0
Barling, K. S., Mcneill, J. W., Paschal, J. C., Mccollum, F. T., Craig, T. M., Adams, L. G., \& Thompson, J. A. (2001). Ranchmanagement factors associated with antibody seropositivity for Neospora caninum in consignments of beef calves in Texas, USA. Preventive Veterinary Medicine, 52(1), 53-61. doi: 10.1016/S0 167-5877(01)00233-1

Castañeda-Hernández, A., Cruz-Vázquez, C., \& Medina-Esparza, L. (2014). Neospora caninum: Seroprevalence and DNA detection in blood of sheep from Aguascalientes, Mexico. Small Ruminant Research, 119(1-3), 182-186. doi: 10.10 16/j.smallrumres.2014.03.002

Cavalcante, A. C. R., Carneiro, M., Gouveia, A. M. G., Pinheiro, R. R., \& Vitor, R. W. (2008). A. Risk factors for infection by Toxoplasma gondii in herds of goats in Ceará, Brazil. Arquivo Brasileiro de Medicina Veterinária e Zootecnia, 60(1), 36-41. doi: 10.1590/ S0102-09352008000100006

Díaz, J. M., Fernández, G., Prieto, A., Valverde, S., Lago, N., Díaz, P.,... Díez-Baños, P. (2014). Epidemiology of reproductive pathogens in semi-intensive lambproducing flocks in North-West Spain: a comparative serological study. Veterinary Journal, 200(2), 335-338. doi: 10.1016/j. tvjl.2014.02.022

Dijkstra, T. H., Barkema, H. W., Bjorkman, C., \& Wouda, W. (2002). A high rate of seroconversion for Neospora caninum in a dairy herd without an obvious increased incidence of abortions. Veterinary Parasitology, 109(3-4), 203-211. doi: 10.10 16/S0304-4017(02)00303-5 
Dubey, J. P., \& Schares, G. (2011). Neosporosis in animals - the last five years. Veterinary Parasitology, 180(1-2), 90-108. doi: 1016/j. vetpar.2011.05.031

Dubey, J. P., Hartley, W. J., Lindsay, D. S., \& Topper, M. J. (1990). Fatal congenital Neospora caninum infection in a lamb. Journal of Parasitology, 76(1), 127-130. doi: $10.2307 / 3282640$

Faria, E. B. E. F. T. S. F., Medeiros, E. S., Pinheiro, J. W., Jr., Azevedo, S. S., Atahayde, A. C. R., \& Mota, R. A. (2010). Risk factors associated with Neospora caninum seropositivity in sheep from the state of Alagoas, in the northeast region of Brazil. Journal of Parasitology, 96(1), 197-199. doi: 10.1645/ GE-2176.1

Ferreira, M. S. T., Vogel, F. S. F., Sangioni, L. A., Cezar, A. S., \& Menezes, F. R. (2016). Neospora spp. and Toxoplasma gondii infection in sheep flocks from Rio Grande do Sul, Brazil. Semina: Ciências Agrárias, 37(3), 1397-1406. doi: 10.5433/1679-0359.2016v37n3p1397

Figliuolo, L. P. C., Kasai, N., Ragozo, A. M. A., Paula, V. S. O., Dias, R. A., Souza, S. L. P., \& Gennari, S. M. (2004). Prevalence of antiToxoplasma gondii and anti- Neospora caninum antibodies in ovine from São Paulo State, Brazil. Veterinary Parasitology, 123(3-4), 161-166. doi: 10.1016/j.vetpar. 2004.06.006

Gazzonis, A. L., Garcia, G. A., Zanzania, S. A., Morab, L. M. O., Invernizzic, A., \& Manfredia, M. T. (2016). Neospora caninum infection in sheep and goats from north-eastern Italy and associated risk factors. Small Ruminant Research, 140, 7-12. doi: 10. 1016/j.smallrumres.2016.05.010
Gharekhani, J., Tavoosidana, G. R., \& Zandieh, M. (2013). Seroprevalence of Neospora caninum in sheep from western Iran. Veterinary World, 6(10), 709-710. doi: 10.14202/vetworld.2013.709-710

Gheller, J. M., Carniel, R., Carrasco, A. O. T., \&Seki, M. C. (2016). Occurrence and risk factors for Toxoplasma gondii and Neospora caninum in sheep of the Guarapuava region, Paraná, Brazil. Brazilian Journal of Veterinary Research and Animal Science, 53(2), 177-181. doi: 10.11606/issn.16784456 v53 i2p177-181

Guimarães, A., Raimundo, J. M., Moares, L. M. B., Silva, A. T., Santos, H. A., Pires, M. S.,... Baldani, C. D. (2015). Occurrences of antiToxoplasma gondii and anti-Neospora caninum antibodies in sheep from four districts of Tocantins state, Brazilian Legal Amazon Region. Pesquisa Veterinária Brasileira, 35(2), 110-114. doi: 10.1590/SO 100-736X2015000200002

Hecker, Y. P., Moore, D. P., Manazza, J. A., Unzaga, J. M., Späth, J. A., Pardini, L. L.,... Campero, C. M. (2013). First report of seroprevalence of Toxoplasma gondii and Neospora caninum in dairy sheep from Humid Pampa, Argentina. Tropical Animal Health and Production, 45(7), 1645-1647. doi: 10.1007s11250-013-0396-1

Helmick, B., Otter, A., Mcgarry, J., \& Buxton, D. (2002). Serological investigation of aborted sheep and pigs for infection by Neospora caninum. Research in Veterinary Science, 73(2), 187-189. doi: 10.1016/ S0034-5288(02)00093-0

Liu, Z. K. B. C., Li, J. Y., \& Pan, H. (2015). Seroprevalence and risk factors of Toxoplasma gondii and Neospora caninum infections in small ruminants in China. 
Preventive Veterinary Medicine, 118(4), 488-492. doi: 10.1016/j.prevetmed.2014. 12.017

Maganga, G. D. B., Abessoloa, A. L., Okouyib, C. S. M., Laboubaa, I., Beyemeb, A. M. M., Mavoungoub, J. F.,... Akue, J. P. (2016). Seroprevalence and risk factors of two abortive diseases, toxoplasmosis and neosporosis, in small ruminants of the Mongo County, southern Gabon. Small Ruminant Research, 144, 56-61. doi: 10. 1016/j.smallrumres.2016.07.022

Mcallister, M. M., Lindsay, D. S., Jolley, W. R., Wills, R. A., Mcguire, A. M., Tress, A. J., \& Stobart, R. H. (1996). Experimental neosporosis in pregnant ewes and their offspring. Veterinary Pathology, 33(6), 647-655. doi: $10.1177 / 030098589603300603$

Moher, D., Liberati, A., Tetzlaff, J., Altman, D. G., Altman, D., Antes, G., \& Tugwell, P. (2009). Preferred reporting items for systematic reviews and meta-analyses: the PRISMA statement. Plos Medicine, 6(7), e1000097. doi: 10.1371/journal.pmed.1000097

Moraes, L. M. M. B., Raimundo, J. M., Guimarães, A., Santos, H. A., Macedo, G. L., Jr., Massard, C. L.,... Baldani,C.D. (2011). Occurrence of anti-Neospora caninum and antiToxoplasma gondii lgG antibodies in goats and sheep in western maranhão, Brazil. Revista Brasileira de Parasitologia Veterinaria, 20(4), 312-317. doi: 10.1590/ S1984-29612011000400010

Moura, A. B. M., Güths, M. F., Farias, J. A., Souza, A. P., Sartor, A. A., \& Quadros, R. M. (2014) Neospora caninum seroprevalence and risk factors for ewes from Santa Catarina Plateau, Brazil. Semina: Ciências Agrárias, 35(5), 2591-2600. doi: 10.5433/1679-0359.2014v35n5p2591
Munhóz, K. F., Luca, M. M. de, Neto, AlmeidaSantos, S. M. de, Garcia, J. L., SilvaGuimarães, J. da, Vidotto, O., \& Yamamura, M. H. (2010). Occurrence of anti-Neospora caninum antibodies in sheep from farms located in northern Parana, Brazil. Semina: Ciencias Agrarias, 31(4), 1031-1040.

$\mathrm{R}$ Core Team (2017). R: A language and environment for statistical computing. Vienna, Austria: R Foundation for Statistical Computing. Retrieved from URL https://www.R-project.org/

Rocha, D. D. S., Guimarães, L. A., Bezerra, R. A., Mendonça, C. E. A., Dórea, T. G., Munhoz, A. D., \& Albuquerque, G. R. (2014). Seroprevalence and factors associated with Neospora caninum infection in sheep from southeastern Bahia, Brazil. Revista Brasileira de Medicina Veterinaria, 36(4), 1-5.

Romanelli, P. R., Freire, R. L., Vidotto, O., Marana, E. R., Ogawa, L., Paula, V. S. O. de,... Navarro, I. T. (2007). Prevalence of Neospora caninum and Toxoplasma gondii in sheep and dogs from Guarapuava farms, Paraná State, Brazil. Research in Veterinary Science, 82(2), 202-207. doi: 10.1016/j. rvsc. 2006.04 .001

Romanelli, P. R. (2002). Avaliação soroepidemiológica de Neospora caninum e Toxoplasma gondii em ovinos do município de Guarapuava-Paraná. Dissertação de mestrado em Sanidade Animal, Faculdade de Medicina Veterinária, Universidade Estadual de Londrina, PR, Brasil.

Salaberry, S. R. S., Okuda, L. H., Nassar, A. F. C., Castro, J. R., Lima-Ribeiro, A. M. C. (2010). Prevalence of Neospora caninum antibodies in sheep flocks 
of Uberlandia county, MG. Revista Brasileira de Parasitologia Veterinária, 19(3), 148-151. doi: 10.1590/S1984-29 612010000300004

Schwarzer, G. (2007). Meta: An R package for meta-analysis. $R$ news, $7(3), 40-45$.

Silva, A. P. S. P., Santos, D. V., Kohek, I., Machado, G., Hein, H. E., Vidor, A. C. M., \& Corbellini, L. G. (2013). Ovinocultura do Rio Grande do Sul: descrição do sistema produtivo e dos principais aspectos sanitários e reprodutivos. Pesquisa Veterinaria Brasileira, 33(12), 1453-1458. doi: 10.15 90/S0100-736 X2013001200010

Tembue, A. A. S. M., Ramos, R. A. N., Sousa, T. R., Alburquerque, A. R., Costa, A. J., Meunier, I. M. J.,... Alves, L.C. (2011). Serological survey of Neospora caninum in small ruminants from Pernambuco State, Brazil. Revista Brasileira de Parasitologia Veterinária, 20(3), 246-248. doi: 10.1590/ S1984-29612011000300013
Tzanidakis, N., Maksimov, P., Conraths, F. J., Kiossis, E., Brozos, C., Sotiraki, S., \&Schares, G. (2012). Toxoplasma gondii in sheep and goats: Seroprevalence and potential risk factors under dairy husbandry practices. Veterinary Parasitology, 190(3-4), 340348. doi: 10.1016/j.vetpar.2012.07.020

Ueno, T. E. H., Gonçalves, V. S. P., Heinemann, M. B., Dilli, T. L. B., Akimoto, B. M., Souza, S. L. P.,... Soares, R. M. (2009). Prevalence of Toxoplasma gondii and Neospora caninum infections in sheep from Federal District, central region of Brazil. Tropical Animal Health Production, 41, 547-552. doi: 10.1007/s11250-008-9220-8

Viechtbauer, W. (2010). Conducting metaanalyses in $\mathrm{R}$ with the metaphor package. Journal of Statistical Software, 36(3), 1-48. doi: 10.18637/jss.v036.i03 
